\title{
Production of biodiesel by transesterification of refined soybean oil
}

\author{
Elizabeth Funmilayo ARANSIOLA ${ }^{1}$, Eriola BETIKU ${ }^{1 *}$, Stephen Kolawole LAYOKUN ${ }^{1}$ \\ and Bamidele Ogbe SOLOMON ${ }^{1,2}$ \\ ${ }^{I}$ Biochemical Engineering Laboratory, Department of Chemical Engineering, Obafemi Awolowo University, \\ Ile-Ife 220005, Osun State, Nigeria. \\ ${ }^{2}$ National Biotechnology Development Agency, P.M.B. 5118, Wuse-Abuja, Nigeria. \\ *Corresponding author: Email: ebetiku@oauife.edu.ng, Telephone: +234-803 6602988
}

\begin{abstract}
This study focused on the production of biodiesel via transesterification of refined soybean oil obtained locally. Sodium hydroxide was used as the alkali catalyst and methanol (as alcohol) was used in the transesterification process due to its low cost. The methanol-to-oil molar ratio was maintained at 6:1. The effect of reaction temperature with time and the catalyst loading were studied. The reaction temperature and the catalyst loading were varied at $30,40,50,60$ and $70{ }^{\circ} \mathrm{C}$; and at 0.5 and $1.0 \%$ weight of oil, respectively. After transesterification of the soybean oil, the fatty acid methyl esters [FAMEs (biodiesel)] conversion was found to rise with an increase in the catalyst loading and also with the reaction temperature but no significant difference $(\mathrm{P}>0.05)$ was found between the temperatures of $60{ }^{\circ} \mathrm{C}$ and $70{ }^{\circ} \mathrm{C}$. The optimum methyl esters conversion of $97.89 \%$ was achieved at $60{ }^{\circ} \mathrm{C}$ for $3 \mathrm{~h}$ with $1 \%(\mathrm{w} / \mathrm{w})$ catalyst. The viscosity $\left(\right.$ at $\left.40{ }^{\circ} \mathrm{C}\right)$, density, cloud point, pour point, flash point and acid number were $3.40 \mathrm{cSt}, 0.86 \mathrm{~g} / \mathrm{ml},-1{ }^{\circ} \mathrm{C},-7{ }^{\circ} \mathrm{C}, 175{ }^{\circ} \mathrm{C}$ and 0.19 , respectively. This optimum methyl esters conversion obtained met ASTM standard of D-6751. Therefore, soybean oil has been shown in this study as a good candidate for biodiesel production and the data acquired can be scaled up for large scale production.
\end{abstract}

(C) 2010 International Formulae Group. All rights reserved.

Keywords: Renewable energy, fatty acid methyl esters, diesel, catalyst.

\section{INTRODUCTION}

The increasing energy demand in the world, the instability in the price of crude oil and pollution problems caused by the widespread use of fossil fuels request for a rapid measure to develop the renewable energy sources such as biodiesel. Biodiesel are fatty acid methyl esters (FAMEs) and fatty acid ethyl esters (FAEEs). Biodiesel, as an alternative fuel, has many merits that make it preferable to the conventional petroleum diesel. It is renewable, biodegradable, environmentally-friendly and non-toxic. Biodiesel can suitably substitute for petroleum diesel because of its properties; especially flash point, cetane number as well as volumetric heating value, which have been shown to be comparable to that of fossil fuelbased diesel (Ma and Hanna, 1999; Lang et al., 2001; Usta, 2005; Jeong et al., 2006).

Biodiesel is produced via conversion of vegetable oils or animal fats or waste oils. 
Such fatty acids-based materials include soybeans, neem seed, jatropha seed, tallow, lard, and waste oil. Soybeans cultivation and utilization which originated in China more than 3000 years ago subsequently spread through the Orient (Hosken, 2003). There have been reports of successful cultivation of soybeans in Africa, Nigeria being the leading producer (Ade-Omowaye et al., 2004). The United States produced 75 million metric tons of soybeans in 2000, representing $50 \%$ of the global production. The World production increased to 219.8 million metric tons in 2007 (Soy Stats, 2008). Total soybean oil availability within this period was 38.4 million metric tons. Fatty acids composition of soybean oil is shown in Table 1.

Various techniques employed in biodiesel production include esterification, transesterification, and hydrotreatment. In the transesterification (Figure 1) of different types of oils or fats, triglycerides react with an alcohol, generally methanol or ethanol, to produce biodiesel and glycerol. Methanol is the most commonly used alcohol because of its low cost. The presence of a catalyst accelerates the conversion. Alkali, acid and enzyme (lipases) are the catalysts that have been reported in transesterification. Alkali catalyst is preferred to acid catalyst in the industries. This is because alkali process is more efficient and less corrosive than the acid process. As for the enzyme-catalyzed system, it requires a much longer reaction time than the other two catalysts (Nelson et al., 1996; Watanabe et al., 2001). Alkali-catalyzed transesterification studies have been reported (Freedman et al., 1984). Parameters that are relevant to transesterification reaction are the free fatty acid contents and water contents in feedstock, oil-to-methanol molar ratio, the catalyst type and amount, the reaction temperature, and the time (Lang et al., 2001; Jeong et al., 2006; Freedman et al., 1984). A 6:1 molar ratio of alcohol to soybean oil and a reaction temperature near the boiling point of the alcohol (e.g. $60{ }^{\circ} \mathrm{C}$ for methanol) were recommended (Noureddini and Zhu, 1997). After the transesterification reaction, different separation techniques to purify the biodiesel product from the other products were investigated by Karaosmanoğlu et al. (1996). They concluded that the use of hot water at 50 ${ }^{\circ} \mathrm{C}$ in washing was the best way to obtain high purity and yield (86\%) of the biodiesel product. Freedman et al. (1984) transesterified peanut, cotton-seed, sunflower and soybean oil under the condition of methanol-oil molar ratio $6: 1,0.5 \%$ sodium methoxide catalyst and $60{ }^{\circ} \mathrm{C}$. An approximate yield of $80 \%$ was observed after $1 \mathrm{~min}$ for soybean and sunflower oils. After $1 \mathrm{~h}$, the conversion was almost the same for all four oils (93-98\%).

In this work, transesterification studies of locally produced soybean oil were carried out by varying reaction temperature and catalyst concentration. This was with a view to establishing the optimum conditions for conversion of the oil to methyl esters and to measure the physical and chemical properties of the biodiesel produced, in order to determine its suitability as replacement for the conventional petroleum diesel.

\section{MATERIALS AND METHODS Materials}

Refined soybean oil, a product of Jof Ideal Family Farms Limited, Vegetable Oil Division, Owo, Ondo State, was bought in Oja Ife Market in Ile-Ife, Osun State. Methanol, sodium hydroxide, anhydrous calcium chloride, n-pentadecane, chloroform, trimethyl sulphonium hydroxide and methyl oleate were all of analytical grade.

\section{Equipment}

Perking Elmer Autosystem gas chromatograph (GC), Brooke Auto viscometer (for determination of viscosity), Koehler Pensky-Martens Flash Cup tester, pour point tester, cloud point tester, Erlenmeyer rotary evaporator and incubator shaker.

\section{Methodology}

\section{Transesterification of the soybean oil}

Batch reactions were carried out in a 250-ml Erlenmeyer flask containing $100 \mathrm{~g}$ of soybean oil. These were done on an incubator 
Table 1: Fatty acid composition of soybean oil.

\begin{tabular}{ccccccc}
\hline \multicolumn{7}{c}{ Fatty acid composition, \% by weight } \\
\hline $\begin{array}{c}\text { Lauric } \\
\left(\mathrm{C}_{12: 0}\right)\end{array}$ & $\begin{array}{c}\text { Myristic } \\
\left(\mathrm{C}_{14: 0}\right)\end{array}$ & $\begin{array}{c}\text { Palmitic } \\
\left(\mathrm{C}_{16: 1}\right)\end{array}$ & $\begin{array}{c}\text { Stearic } \\
\left(\mathrm{C}_{18: 0}\right)\end{array}$ & $\begin{array}{c}\text { Oleic } \\
\left(\mathrm{C}_{18: 1}\right)\end{array}$ & $\begin{array}{c}\text { Linoleic } \\
\left(\mathrm{C}_{18: 2}\right)\end{array}$ & $\begin{array}{c}\text { Linolenic } \\
\left(\mathrm{C}_{18: 3}\right)\end{array}$ \\
\hline 0.10 & 0.10 & 10.20 & 3.70 & 22.80 & 53.70 & 8.60 \\
\hline Source: Marchetti et al., 2007 & & & & &
\end{tabular}<smiles></smiles>

Triglyceride

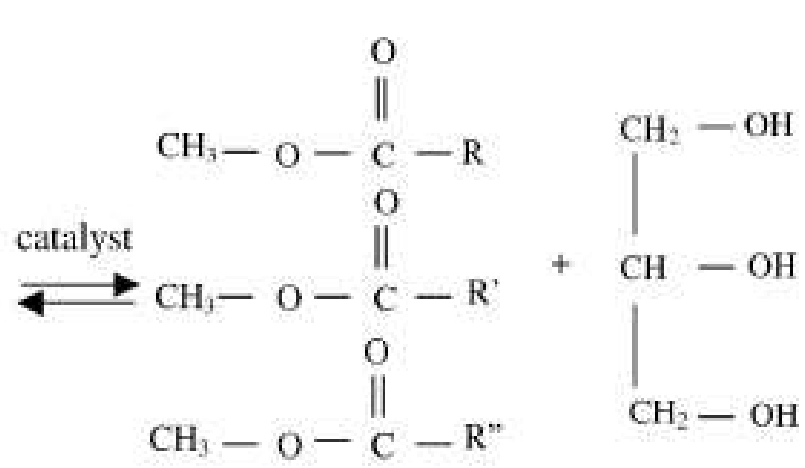

Figure 1: The overall chemical reaction of the transesterification process.

shaker at different temperatures of $30,40,50$, 60 and $70{ }^{\circ} \mathrm{C}$, keeping the rate of agitation and oil to alcohol ratio constant at $200 \mathrm{rpm}$ and $1: 6$, respectively. Catalysts of $0.5 \%(\mathrm{w} / \mathrm{w})$ and $1 \%(\mathrm{w} / \mathrm{w})$ of sodium hydroxide were used. The catalyst was dissolved into methanol according to the oil to alcohol ratio (1:6). The oil was heated up to reaction temperature in the Erlenmeyer flask and once the alkali got dissolved, the alcohol-alkali mixture was added to the oil, and the reaction was allowed to run for various periods of $0.25,0.50,1,2$ and $3 \mathrm{~h}$. These samples were allowed to settle overnight in a separating funnel by gravity, settling into a clear, golden liquid biodiesel on the top with the light brown glycerol at the bottom. On the second day the glycerol was drained off from the bottom of the separating funnel. The raw biodiesel was washed with water three times to remove the unreacted catalyst and glycerol. To get a pure biodiesel, this was purified in a rotary evaporator to remove any excess methanol. Following this, the ester phase was dried over anhydrous calcium chloride. The methyl esters produced were analyzed for the following parameters: methyl esters, pour point, cloud point, flash point, density, kinematic viscosity at $40{ }^{\circ} \mathrm{C}$ and acid number.

\section{Analysis of the soybean-based biodiesel}

Determination of soybean-based biodiesel concentration

$$
\text { Analyses were performed on the }
$$

Perking Elmer Autosystem Gas Chromatograph with flame ionization detector. Methyl esters concentration determination was done according to the modified methods of Freedman et al. (1984), Mariani et al. (1991) and Foidl et al. (1996). The Gas Chromatograph was equipped with a $30 \mathrm{~m}$ capillary column (ID $0.25 \mathrm{~mm} / 0.50 \mu \mathrm{m}$ ) and reference standard used was methyl oleate (Sigma) while the internal standard and the solvent used were n-pentadecane (Merck, Germany) and Chloroform (analytical grade), respectively. The initial temperature $\left(160{ }^{\circ} \mathrm{C}\right)$ was raised at a rate of $10{ }^{\circ} \mathrm{C} / \mathrm{min}$ to $230{ }^{\circ} \mathrm{C}$ 
and then at a rate of $20{ }^{\circ} \mathrm{C} / \mathrm{min}$ to $300{ }^{\circ} \mathrm{C}$. Sample was prepared by diluting $10 \mathrm{mg}$ of the ester in $100 \mu \mathrm{l}$ of $1.5 \%$ of internal standard solution ( $\mathrm{n}$-pentadecane in chloroform). To $50 \mu \mathrm{l}$ of the solution, $50 \mu \mathrm{l}$ of trimethyl sulphonium hydroxide were added.

\section{Characterization of soybean-based biodiesel}

For the characterization of the biodiesel produced, parameters determined with the standard methods used are presented in Table 2. Flash point was determined by the Flash cup closed tester.

Cloud and pour points were determined simultaneously using the Pour and Cloud Point tester. Density and the viscosity were measured at $40{ }^{\circ} \mathrm{C}$ using the density bottle and the Brooke Auto Viscometer, respectively. The acid value is defined as the amount of potassium hydroxide $(\mathrm{mg})$ needed to neutralize fatty acids in $1 \mathrm{~g}$ of sample. It shows the amount of free fatty acid content in biodiesel produced. Here, indicator solution (1.0\% phenolphthalein indicator in isopropyl alcohol) was added to the required amount of solvent (equal parts by volume of isopropyl alcohol and toluene) in ratio of $2 \mathrm{ml}$ to $125 \mathrm{ml}$ and neutralize with alkali to a faint but permanent pink colour. Five grams of the well mixed sample was weighed into an Erlenmeyer flask and $125 \mathrm{ml}$ of the neutralized solvent mixture was added. It was ensured that the sample was completely dissolved before titration was carried out. The sample was shaken vigorously while titrating with the standard alkali $(0.1 \mathrm{~N} \mathrm{KOH})$ until the first permanent pink colour was reached. The acid value was calculated using Equation (1).

Acid value (mg KOH/g of sample) $=\frac{(\mathrm{A}-\mathrm{B}) * \mathrm{~N} * 56.1}{\mathrm{~W}}$

Where $\mathrm{A}=$ volume of standard alkali used in the titration $(\mathrm{ml})$,

$\mathrm{B}=$ volume of standard alkali used in titrating the blank (ml),

$\mathrm{N}=$ normality of standard alkali

$\mathrm{W}=$ mass of sample $(\mathrm{g})$.

\section{Statistical analysis}

The One-way ANOVA was performed with Origin 7 statistical software.

\section{RESULTS}

Soybean-based biodiesel production

Transesterification method employed in this work for the soybean-based biodiesel production gave excellent results. The byproduct, glycerol was separated under gravity with the aid of the separating funnel within a few hours. It was observed that glycerol settled at the bottom of the funnel, indicating that the by-product is denser than the crude biodiesel product. The process of purification adopted in this work proved to be effective in getting pure biodiesel.

\section{Studies on variation of reaction temperature and catalyst loading}

Figures 2 and 3 show results obtained in the investigation of varying reaction temperature and catalyst concentration for the transesterification of soybean oil into methyl esters. For all the studies carried out, as the transesterification time increased, the percentage conversion increased. Furthermore, the results showed that irrespective of the concentration of the catalyst used $(0.5$ or $1 \% \mathrm{w} / \mathrm{w})$, as the temperature increased, the percentage conversion of soybean oil into methyl esters also increased. Conversion observed at $30{ }^{\circ} \mathrm{C}$ was lower than the results of other studies carried out at reaction temperatures of 40, 50, 60 and $70{ }^{\circ} \mathrm{C}$. After $2 \mathrm{~h}$ of transesterification, there was about $10 \%$ increase in the percentage of conversion at reaction temperature of $60{ }^{\circ} \mathrm{C}$ compared to that of 30 ${ }^{\circ} \mathrm{C}$ (Figures 2 and 3). This observation is irrespective of the concentration of the catalyst used. It was noted also that results for both $60{ }^{\circ} \mathrm{C}$ and $70{ }^{\circ} \mathrm{C}$ reaction temperatures were similar. The data obtained showed that at the 0.05 significance level, the results were not significantly different. 
Table 2: Standard methods for biodiesel characterization.

\begin{tabular}{lc}
\hline Property of Ester & Test Method \\
\hline Viscosity & ASTMD -445 \\
Density & ASTMD -287 \\
Flash Point & ASTMD -93 \\
Pour Point & ASTMD -97 \\
Cloud Point & ASTMD -2500 \\
Moisture Content & ASTMD -2709 \\
Acid Number & AOCS Method Te la -64 \\
\hline
\end{tabular}

However, the data obtained when $1 \%$ (w/w) catalyst was employed were better than when $0.5 \%(\mathrm{w} / \mathrm{w})$ catalyst was used. After $3 \mathrm{~h}$ of transesterification, the percentage conversions recorded were 97.89 and 97.55 for reaction temperatures $60{ }^{\circ} \mathrm{C}$ and $70{ }^{\circ} \mathrm{C}$, respectively when catalyst loading of $1 \%$ (w/w) was used, while the percentage conversions were 93.36 and 93.45 for reaction temperatures $60{ }^{\circ} \mathrm{C}$ and $70{ }^{\circ} \mathrm{C}$, respectively, when catalyst loading of $0.5 \%(\mathrm{w} / \mathrm{w})$ was employed. In general, the optimum result was observed at a reaction temperature of $60{ }^{\circ} \mathrm{C}$ and catalyst concentration of $1 \% \quad(w / w)$. Besides the higher percentage of conversion, working with reaction temperature of $60{ }^{\circ} \mathrm{C}$ is preferable to $70{ }^{\circ} \mathrm{C}$, because the boiling point of methanol is $60{ }^{\circ} \mathrm{C}$. The alcohol will be lost via evaporation at higher temperature than its boiling point. Methanolysis of soybean oil with $1 \%$ potassium hydroxide catalyst gave the best yields and viscosities of the esters (Tomasevic and Marinkovic, 2003). It has been reported that the amount of catalyst that should be added to the reactor should vary from $0.5 \%$ to $1 \%(\mathrm{w} / \mathrm{w})$ (Srivastava and Prasad, 2000; Barnwal and Sharma, 2005).

Table 3 shows the effect of reaction temperature on the viscosity of the transesterified oil. The viscosity decreases slightly as the temperature increases. All the values observed fell within the limit set for diesel fuel (Table 4). The kinematic viscosity showed a reduction of about $90 \%$ after the soybean oil was converted to biodiesel via transmethylation process in all the reaction temperatures investigated (Table 3). Viscosity of vegetable oil at $35.39 \mathrm{cSt}$ may trigger severe problems in the fuel filter and the engine. Knothe (2005) reported that high viscosity of untransesterified oils and fats leads to operational problems in the diesel engine such as deposits on various engine parts.

Table 4 shows the properties of the biodiesel produced under optimum conditions, refined soybean oil, the Automotive Gas Oil (AGO) and fuel limit. The properties of the soybean-based biodiesel produced are in close agreement with the standard values (Table 4). Also, the characteristics of the biodiesel compared favourably well with that of petroleum diesel (AGO). The results suggest that the biodiesel produced from soybean can suitably substitute for AGO.

\section{DISCUSSION}

This research was undertaken with the aim of establishing the possibility of using locally produced soybean oil for the production of biodiesel. Results from this present study are comparable to those earlier reported. Ali et al. (1995) reported the following properties for biodiesel produced from soybean oil: kinematic viscosity, 4.5 $\mathrm{mm}^{2} / \mathrm{s}$; cloud point, $1{ }^{\circ} \mathrm{C}$; pour point, $-7{ }^{\circ} \mathrm{C}$; flash point, $178{ }^{\circ} \mathrm{C}$ and density, $885 \mathrm{~kg} / \mathrm{m}^{3}$. Boocock et al. (1998) carried out transesterification of soybean oil with methanol at different concentrations of sodium hydroxide. The reported ester contents after $1 \mathrm{~min}$ for $1.1,1.3,1.4$ and $2.0 \%$ sodium hydroxide were $82.5,85,87$ and $96.2 \%$, respectively. They suggested that hydroxide concentration could be increased up to 1.3 


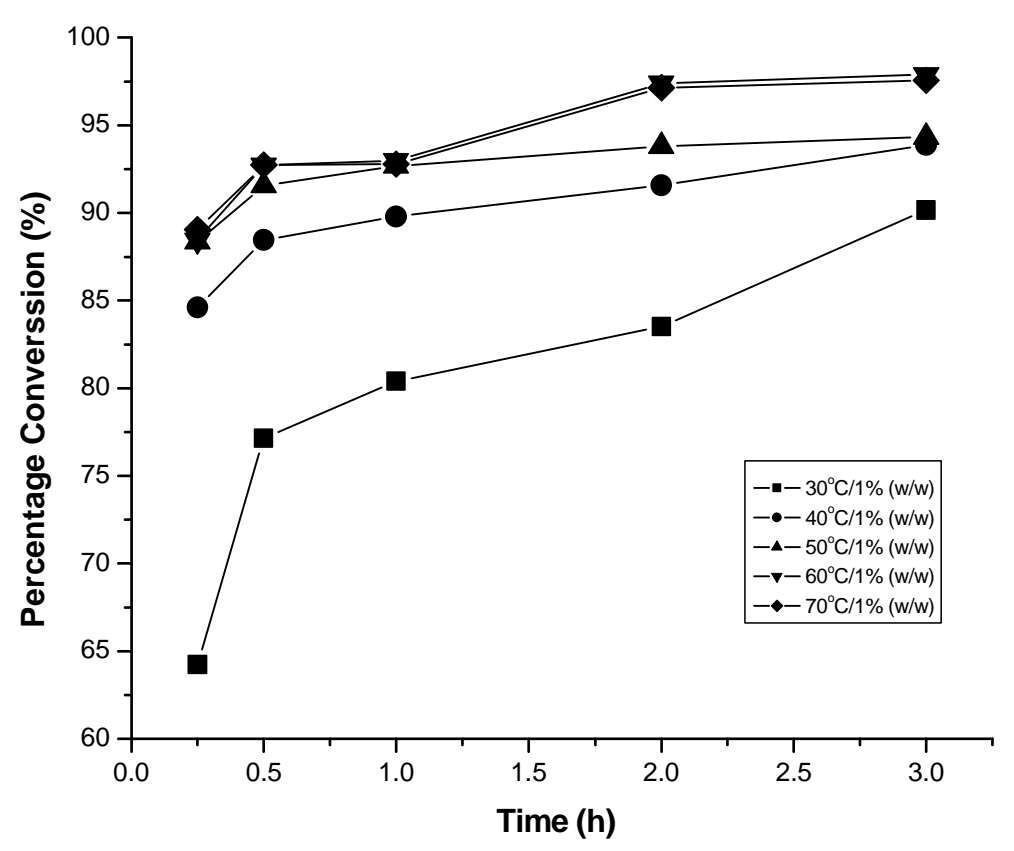

Figure 2: Plot of percentage conversion against time for the $1 \%(\mathrm{w} / \mathrm{w})$ alkali catalyst during transesterification of soybean oil.



Figure 3: Plot of percentage conversion against time for the $0.5 \%(\mathrm{w} / \mathrm{w})$ alkali catalyst during transesterification of soybean oil. 
Table 3: Effect of varying temperature with time on kinematic viscosity of soybean-based biodiesel.

\begin{tabular}{cccccc}
\hline \multirow{2}{*}{$\begin{array}{c}\text { Time } \\
\text { (h) }\end{array}$} & $\mathbf{3 0}^{\mathbf{0}} \mathbf{C}$ & $\mathbf{4 0}^{\mathbf{0}} \mathbf{C}$ & $\mathbf{5 0}^{\mathbf{}} \mathbf{C}$ & $\mathbf{6 0}^{\mathbf{0}} \mathbf{C}$ & $\mathbf{7 0}^{\mathbf{0}} \mathbf{C}$ \\
\cline { 2 - 6 } & $3.73 \pm 0.000$ & $3.65 \pm 0.002$ & $3.61 \pm 0.001$ & $3.62 \pm 0.000$ \\
0.25 & $3.75 \pm 0.005$ & $3.62 \pm 0.001$ & $3.60 \pm 0.000$ & $3.55 \pm 0.001$ & $3.58 \pm 0.000$ \\
0.5 & $3.76 \pm 0.028$ & $3.60 \pm 0.004$ & $3.57 \pm 0.002$ & $3.44 \pm 0.000$ & $3.44 \pm 0.001$ \\
1 & $3.74 \pm 0.000$ & $3.57 \pm 0.000$ & $3.56 \pm 0.001$ & $3.40 \pm 0.000$ & $3.41 \pm 0.001$ \\
2 & $3.68 \pm 0.007$ & $3.67 \pm 0.007$ & $3.56 \pm 0.001$ & $3.40 \pm 0.000$ & $3.39 \pm 0.001$ \\
3 & $3.62 \pm 0.000$ & 3.00 &
\end{tabular}

Table 4: Properties of soybean-based biodiesel, soybean oil and automotive gas oil (AGO).

\begin{tabular}{|c|c|c|c|c|}
\hline Properties & Soybean-based Biodiesel & Soybean oil & AGO & *Limit \\
\hline Viscosity @ 40 ${ }^{\circ} \mathrm{C}(\mathrm{cSt})$ & 3.40 & 35.39 & 3.073 & $3.5-5.0$ \\
\hline Flash Point $\left({ }^{\circ} \mathrm{C}\right)$ & 175 & - & 71 & Min 100 \\
\hline Pour Point $\left({ }^{\circ} \mathrm{C}\right)$ & -7 & - & -16 & - \\
\hline Cloud point $\left({ }^{\circ} \mathrm{C}\right)$ & -1 & - & -12 & $-1.0-4.0$ \\
\hline Density @ RT (kg/m³) & 860 & 890 & 860 & $860-900$ \\
\hline Acid number, mg KOH/g & 0.19 & 0.38 & - & Max 0.5 \\
\hline
\end{tabular}

wt $\%$, resulting in $95 \%$ methyl ester after 15 min. Using $1 \%$ sodium hydroxide in this present study, $\sim 98 \%$ methyl ester was produced in $3 \mathrm{~h}$. Noureddini and Zhu (1997) recommended a 6:1 molar ratio of alcohol to soybean oil which was adopted in this work and a reaction temperature near the boiling point of the alcohol $\left(60{ }^{\circ} \mathrm{C}\right.$ for methanol). Optimal conversion of soybean oil to methyl ester was also established under these conditions in this work. Methanolysis of soybean oil with $1 \%$ potassium hydroxide catalyst has given the best yields and viscosities of the esters (Tomasevic and Marinkovic, 2003). It has been reported that the amount of catalyst that should be added to the reactor should vary from $0.5 \%$ to $1 \%$ (w/w) (Srivastava and Prasad, 2000; Barnwal and Sharma, 2005). Freedman et al. (1984) transesterified peanut, cotton-seed, sunflower and soybean oil under the condition of methanol-oil molar ratio of $6: 1,0.5 \%$ sodium methoxide catalyst and $60{ }^{\circ} \mathrm{C}$. An approximate yield of $80 \%$ was observed after $1 \mathrm{~min}$ for soybean and sunflower oils. After $1 \mathrm{~h}$, they observed that the conversion was almost the same for all four oils (93-98\%). At a reaction temperature of $65{ }^{\circ} \mathrm{C}$, the conversion was completed in $20 \mathrm{~h}$. Results on the kinematic viscosity obtained in this work showed a reduction of about $90 \%$ after the soybean oil was converted to biodiesel via transmethylation process at all the reaction temperatures investigated. Viscosity of vegetable oil at $35.39 \mathrm{cSt}$ may trigger severe problems in the fuel filter and the engine. Knothe (2005) reported that high viscosity of untransesterified oils and fats leads to operational problems in the diesel engine such as deposits on various engine parts.

\section{Conclusion}

In this study, we determined the optimum conditions for transesterification of 
soybean oil into methyl esters by varying the reaction temperature and catalyst loading. The conditions established were: $60{ }^{\circ} \mathrm{C}$ reaction temperature and $1 \%(\mathrm{w} / \mathrm{w})$ alkali catalyst loading using soybean oil-to-methanol molar ratio of $6: 1$. The properties of soybean-based biodiesel produced satisfied ASTM standard of D-6751, hence, it can act as alternative fuels for the Internal Combustion Engines (ICE). Soybean oil has been shown in this study as a very good candidate for biodiesel production and the data acquired can be scaled up for large scale production.

\section{ACKNOWLEDGEMENTS}

E. F. Aransiola gratefully acknowledges the financial support of Carnegie Corporation of New York and Prof. Harrison of University of Cape Town, South Africa for providing working space for carrying out part of these studies.

\section{REFERENCES}

Ade-Omowaye BIO, Olajide JO, Otunola ET, Omotade VA. 2004. Effect of some processing parameters on the quality characteristics of soybean curd. Science Focus, 7: 53-57.

Ali Y, Hanna MA, Cuppett SL. 1995. Fuel properties of tallow and soybean oil esters. J. Am. Oil Chem. Soc., 72(12): 1557-1564.

Antolin G, Tinaut FV, Briceno Y, Castano V, Perez C, Ramiez AI. 2002. Optimization of biodiesel production by sunflower oil transesterification. Bioresour. Technol., 83: 111-114.

Barnwal BK, Sharma MP. 2005. Prospects of biodiesel production from vegetable oils in India. Renew. Sustain. Energ. Rev., 9: 363-378.

Boocock DGB, Konar SK, Mao V, Lee C, Bulugan S. 1998. Fast formation of highpurity methyl esters from vegetable oils. J. Am. Oil Chem. Soc., 75(9): 1167-1172.

Foidl N, Foidl G, Sanchez M, Mittelbach M, Hackel S. 1996. Jatropha curcas L., as a source for the production of biofuel in Nicaragua. Bioresour. Technol., 58: 7782.

Freedman B, Pryde EH, Mounts TL. 1984. Variables affecting the yields of fatty esters from transesterified vegetable oils. J. Am. Oil Chem. Soc., 61(10): 16381643.

Freedman B, Butterfield RO, Pryde EH. 1986. Transesterification kinetics of soybean oil. J. Am. Oil Chem. Soc., 63: 13751380.

Hosken B. 2003. Advances in soybean processing and utilization. Highlighting Soybeans - Nutritional Characteristics for Edible Soybeans, $12^{\text {th }}$ Australian Soybean Conference Proceeding, www.australian oilseeds.com

Jeong GT, Oh YT, Park DH. 2006. Emission profile of rapeseed methyl ester and its blend in a diesel engine. Appl. Biochem. Biotechnol., 129-132: 165-178.

Karaosmanoğlu F, Cigizoglu KB, Tuter M, Ertekin S. 1996. Investigation of the refining step of biodiesel production. Energy Fuels, 10: 890-895.

Knothe G. 2005. What is Biodiesel? In The Biodiesel Handbook, Knothe G, Gerpen JV, Krahl J (eds). AOCS Press: Champaign Illinois; 1-3.

Lang X, Dalai AK, Bakhshi NN, Reaney MJ, Hertz PB. 2001. Preparation and characterization of bio-diesels from various bio-oils. Bioresour. Technol., 80: 53-62.

Ma F, Hanna MA. 1999. Biodiesel production: a review. Bioresour. Technol., 70: 1-15.

Marchetti JM, Miguel VU, Errazu AF. 2007. Possible method's for biodiesel production. Renew. Sustain. Energ. Rev., 11(6): 1300-1311.

Mariani C, Bondioli P, Venturini S, Fedeli E. 1991. Vegetable oil derivatives as diesel fuel: Analytical aspects. Note 1: Determination of methyl esters, mono-, di-, and triglycerides. La Rivista 
Italiana delle Sostanze Grasse, 68(10): 549-551.

Nelson LA, Foglia TA, Marmer WN. 1996. Lipase-catalyzed production of biodiesel. J. Am. Oil Chem. Soc., 73(8): 1191-1195.

Noureddini H, Zhu D. 1997. Kinetics of transesterification of soybean oil. J. Am. Oil Chem. Soc., 74: 1457-1463.

Soy Stats, World Soybean Production. 2008. http://www.soystats.com/2008/Defaultframes.htm

Srivastava A, Prasad R. 2000. Triglyceridesbased diesel fuels. Renew. Sustain. Energ. Rev., 4: 111-133.
Tomasevic AV, Marinkovic SS. 2003. Methanolysis of used frying oils, Fuel Process Technol., 81: 1-6.

Usta N. 2005. Use of tobacco seed oil methyl ester in a turbocharged indirect injection diesel engine. Biomass Bioenergy, 28(1): 77-86.

Watanabe Y, Shimada Y, Sugihara A, Tominaga Y. 2001. Enzymatic conversion of waste edible oil to biodiesel fuel in a fixed bed bioreactor. J. Am. Oil Chem. Soc., 78(2): 703-707. 